\section{Has Japan Been Left Out in the Cold by Regional Integration?}

\author{
Howard J. Wall
}

\section{INTRODUCTION}

$\triangle$ regional trading bloc (RTB) is a grouping of countries in which trade between members faces fewer restrictions (i.e., tariffs, quotas, nontariff barriers) than trade between a member and a nonmember. One of the most significant recent trends in international trade has been the increasing importance of RTBs, which have been growing in both number and size for over a decade. ${ }^{1}$ Not all countries have followed the trend toward regional integration, though, and relatively little research has examined the effects of regional integration on non-integrators. This paper attempts to fill this void by estimating the effects of several major RTBs on the trade pattern of the largest nonintegrator, Japan.

From the perspective of Japanese trade, the two most important RTBs are the North American and European trading blocs, whose most recent regimes are the North American Free Trade Agreement (NAFTA) and the European Economic Area (EEA). NAFTA was inaugurated in 1994, bringing Mexico into the RTB that had been in place between Canada and the United States since 1989. The EEA includes the 15 members of the European Union (EU) and the four members of the European Free Trade Area (EFTA). It was formed in 1995, although the EU and EFTA had maintained separate RTBs of varying depth and breadth since 1957 and 1960, respectively.

A third bloc, the Association of South East Asian Nations Free Trade Area (AFTA), is potentially as

Howard J. Wall is a research officer at the Federal Reserve Bank of St. Louis; this research was done while he was a visiting scholar at the Institute for Monetary and Economic Studies (IMES) of the Bank of Japan (BOJ) during the spring of 2001 and was previously published (Institute for Monetary and Economic Studies, Bank of Japan, Monetary and Economic Studies, April 2002, 20(2), pp. 117-34). The author thanks the IMES and the BOJ for hospitality and research resources and the seminar participants at the IMES, Hitotsubashi University, and the Research Institute of Economy, Trade, and Industry for their comments. The views expressed are the author's alone and are not necessarily those of the IMES, the BOJ, the Federal Reserve Bank of St. Louis, or the Federal Reserve System.

(c) 2002, The Federal Reserve Bank of St. Louis. important for Japan as the EEA: each bloc accounts for around 16 percent of Japan's trade. ${ }^{2}$ AFTA, however, has not been nearly as deep an integration regime, so its importance for Japan is yet to be fully realized. Frankel (1997) reports dozens of other RTBs around the world, most of which are among small countries. The most important of these from a Japanese perspective are the Australia-New Zealand Closer Economic Relations Trade Agreement (ANZCERTA), the Mercado Comùn del Sur (Mercosur), and the Andean Community. ${ }^{3}$

Japan has been notably reluctant to follow the trend toward regional integration, maintaining a multilateral approach through the World Trade Organization (WTO), while monitoring RTBs for any tendencies toward higher protection against nonmembers (Ministry of Economy, Trade, and Industry, 2001). Recently, though, Japan has taken a more nuanced, "multilayered" approach designed to extract the benefits of multilateral integration while avoiding many of the discriminatory consequences associated with RTBs. ${ }^{4}$ As described by Eguchi (2001), one of the main reasons for this new approach is to establish footholds within existing RTBs to avoid some of the discriminatory tariff treatment that Japanese goods would face otherwise. This approach has led to recent bilateral discussions with Singapore, South Korea, Mexico, and Chile.

For the time being, however, Japan has bucked the regional integration trend while its trading partners have become increasingly regionally integrated: by the late 1990s, more than 60 percent of Japan's total trade (imports plus exports) was with countries that were members of the six trading blocs described above. As a consequence, there has been ongoing concern that Japan has been left at a disadvantage when its firms compete within RTB markets, and that its trade patterns have been disrupted. To date, though, I have found little research done on the extent to which RTBs have affected

\footnotetext{
1 See Frankel (1997) for excellent descriptions and histories of the various RTBs.

2 AFTA includes Brunei, Indonesia, Malaysia, the Philippines, Singapore, and Thailand. Although a trade bloc of sorts had been in place since 1978, its coverage was extremely limited. AFTA was created in 1992 and began to be implemented in subsequent years (Frankel, 1997).

3 1995 and includes Argentina, Brazil, Paraguay, and Uruguay. The Andean Community includes Bolivia, Colombia, Ecuador, Peru, and Venezuela

4 See Eguchi (2001) and Kojima (2001) for discussions of RTBs from Japan's perspective.
} 
Japan, although Anderson and Snape (1994) argue that many of the concerns among non-integrating Asian countries are unwarranted.

Because this paper focuses on the effects of RTBs on a nonmember, it is in a minority of research on RTBs, as nearly all previous research has been from the perspective of member countries. ${ }^{5}$ For member countries, the trade effects are usually categorized as trade creation (the supposed increase in trade between members) and trade diversion (the supposed decrease in imports from nonmembers). This dichotomy has dominated the discussion of the effects of RTBs since Viner (1950) first used it to establish the general welfare ambiguity of RTBs for member countries. For nonmembers, the usual presumption has been that the reduction in exports to RTB members would make them worse off.

The empirical analysis of the trade effects of RTBs has advanced little beyond the Vinerian effects, even though they were derived in a simple singleindustry partial equilibrium model. As shown by Winters (1997), however, in a standard general equilibrium model, an RTB affects not only a member's imports from nonmembers, but also its exports to them. This aspect of RTBs is usually ignored in empirical studies, and when it has been considered, imports and exports are often lumped together under the extremely suspect assumption that Vinerian trade diversion applies to exports as well as imports. Further, as argued by Wall (2000) and Cheng and Wall (2001), under capital mobility an RTB will affect not just the quantities that firms produce, but also the countries in which production takes place. This has obvious implications for Japan's trade pattern for, as shown by Head and Ries (2001) and Lipsey, Ramstetter, and Blomström (2000), Japanese firms that increase their manufacturing investment overseas also tended to increase their exports.

The effects of RTBs on trade between members and nonmembers discussed in the preceding paragraphs arise even when the level of protection toward nonmembers is unaffected by integration. An emerging literature, though, has looked at how joining an RTB can change levels of protection. In Yi (2000) and Kose and Riezman (2000), if the RTB is a free trade area-in which members set their own tariffs - tariffs are lower after integration. On the other hand, a customs union-in which members have a common tariff_-might lead to higher post-integration tariffs (Kose and Riezman, 2000, and Bandyopadhyay and Wall, 1999).

To summarize, even assuming that capital does not migrate in response to RTBs, it is not necessarily true that Japanese trade with an RTB's members will be reduced, despite the presumed certainty of trade diversion. Also, once you consider the mobility of capital, it is possible that some or all RTBs have led to increases in Japanese exports and/or imports. And finally, the level of protection toward nonmembers can change after integration, and the direction of this change can depend on the type of integration that is chosen. What this means is that the question posed by the title of this paper is not as straightforward as would be suggested by the simple Vinerian dichotomy. It is not possible to make reliable a priori predictions about the signs of the effects of an RTB on Japanese trade.

The rest of the paper is organized as follows. Section II briefly discusses some recent trends in Japanese trade, particularly those regarding trade with major RTBs. The empirical model is presented in Section III, and Section IV presents the empirical results. Concluding remarks are presented in Section V.

\section{RECENT TRENDS IN JAPANESE TRADE}

The bilateral trade data that I use come from the World Trade Flows dataset described in detail by Feenstra (2000). These data are the United Nations trade data recompiled by Statistics Canada to make them consistent across countries and over time. This recompiling is necessary to avoid various problems with the original data, including discrepancies between import and export reports, i.e., A's reported exports to B do not match B's reported imports from A. Unfortunately, because of the scale of the project, the data are available only with long lags, meaning that 1997 is the latest year available.

As illustrated by Figure 1, Japanese real total trade (imports plus exports) measured in U.S. dollars trended upward between 1986 and 1997, peaking in 1995 at nearly 60 percent above its 1986 level. ${ }^{6}$ However, looking at total trade relative to the size of the Japanese economy, this consistent upward trend disappears. By 1993, total trade as a percent of GDP had fallen to 13.5 percent, having risen to nearly 17.5 percent in 1986 and 1990. By 1997 ,

\footnotetext{
5 Exceptions include Winters (1997), Goto and Hamada (1998, 1999), and Winters and Chang (2000).

6 This is at market exchange rates and the U.S. consumer price index relative to average prices for 1982-84.
} 


\section{Figure 1}

Japan's Real Total Trade (Imports plus Exports)

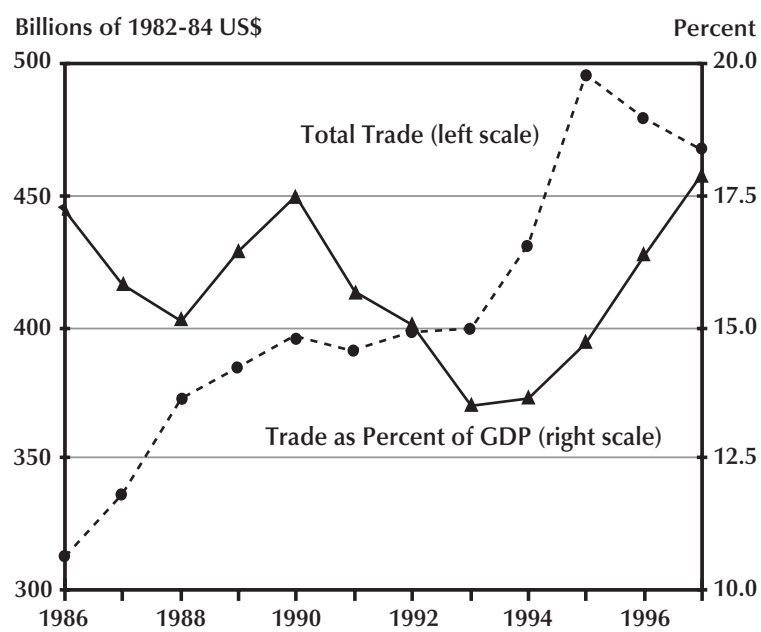

SOURCE: World Trade Flows 1980-97 and the World Bank.

though, it had recovered and was back at a new peak for the period of close to 18 percent.

Figures 2 and 3 illustrate how export and import trends differed somewhat from each other. While real imports and exports were both significantly higher in 1997 than in 1986, real imports did not rise steadily, and even fell by more than 15 percent between 1990 and 1993. Real exports, on the other hand, rose steadily throughout the period. Also, despite the dip in the early 1990s, real growth in imports between 1986 and 1997 (82 percent) easily outstripped the growth in real exports (32 percent). Further evidence of the trend toward imports relative to exports is that exports as a percentage of GDP were actually slightly lower in 1997 than in 1986, whereas imports as a percentage of GDP were nearly onethird higher over the same period. Greaney (2001) notes that the increase in imports has not been due to an opening of Japanese markets to imports, but is related to increased imports from overseas affiliates of Japanese firms and importing by Japan-based affiliates of foreign firms. ${ }^{7}$

The primary concern of this paper is the geographic allocation of Japanese trade across RTBs, which, as shown by Figure 4, has seen some changes in recent years. ${ }^{8}$ The most notable of these has been the decreasing importance of the members of the North American and European trading blocs relative to members of AFTA. The decline in North America's share extended over the whole period, although

\section{Figure 2}

\section{Japan's Real Imports and Exports}

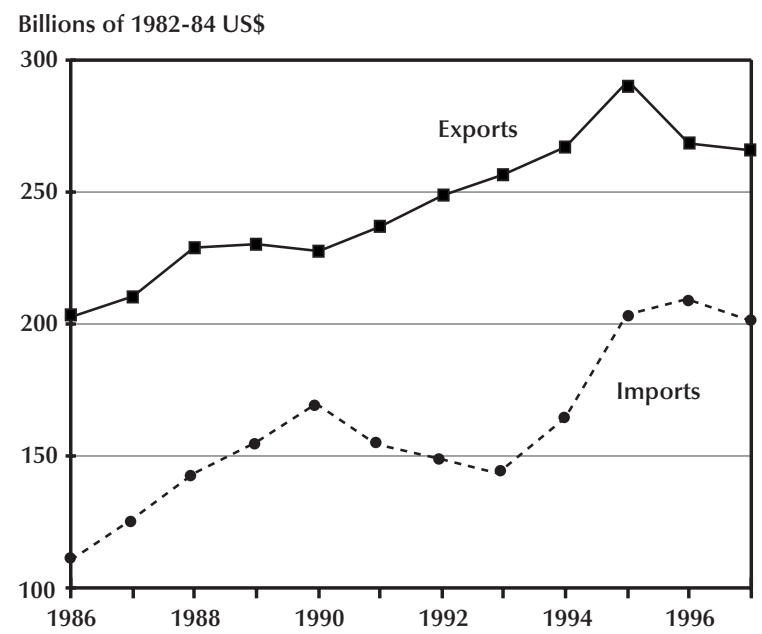

SOURCE: World Trade Flows 1980-97.

\section{Figure 3}

Japan's Imports and Exports Relative to GDP

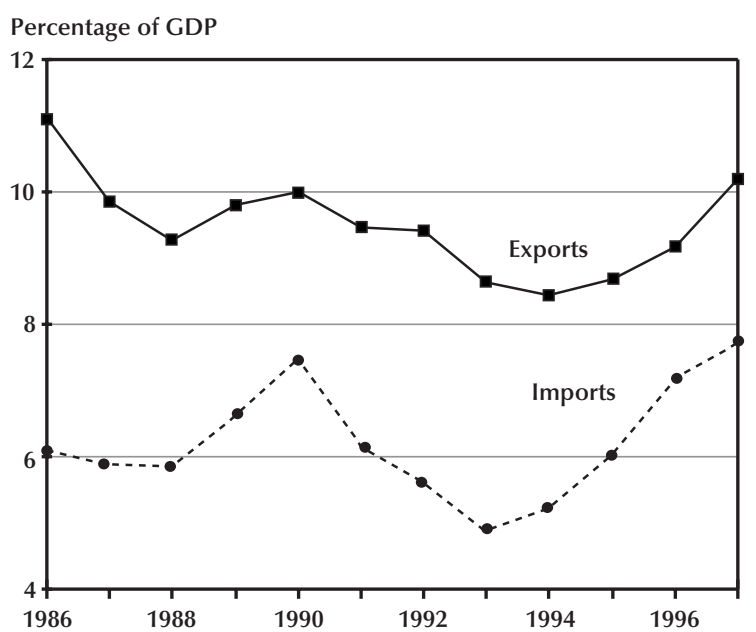

SOURCE: World Trade Flows 1980-97 and the World Bank.

\footnotetext{
7 She finds that "by the late 1990s, slightly over half of Japan's imports are... provided by Japanese affiliates abroad and approximately one quarter of imports are purchases made by foreign affiliates in Japan."

8 To construct these figures, trade in a given year is the total of trade with all countries that were members of the respective blocs in 1997.
} 


\section{Figure 4}

\section{Major Blocs' Shares of Japan's Total Trade}

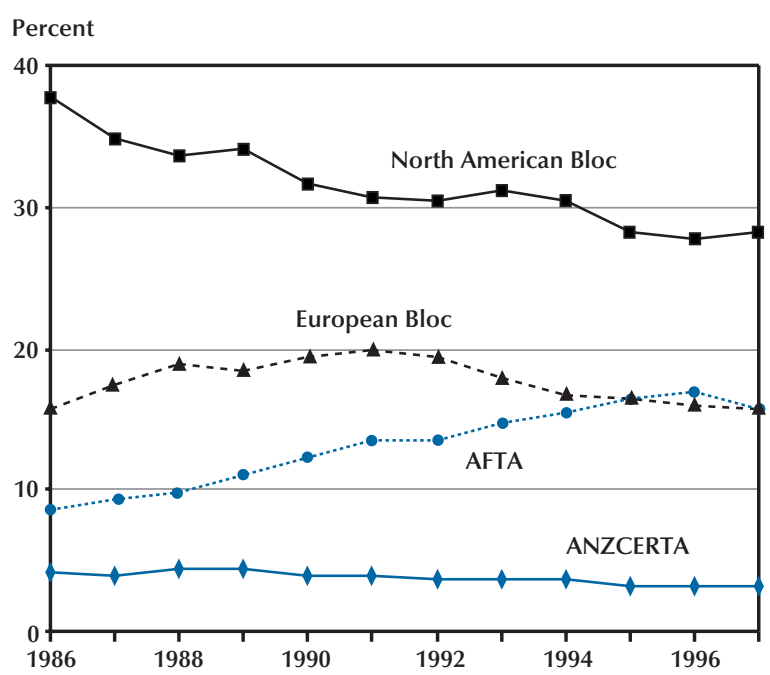

SOURCE: World Trade Flows 1980-97.

\section{Figure 5}

\section{Major Blocs' Shares of Japan's Exports}

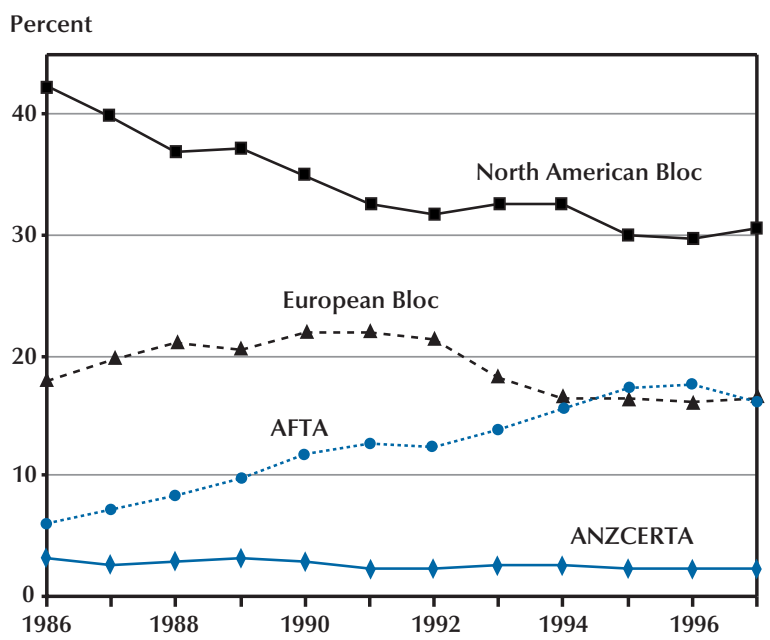

SOURCE: World Trade Flows 1980-97.

there is evidence that it was encouraged by regional integration. There was a noticeable drop in the North American bloc's share following integration between the United States and Canada in 1989, and again following the addition of Mexico in 1994. Similarly, for Japanese trade with the European bloc, there was a notable turning point after 1992, when

\section{Figure 6}

\section{Major Blocs' Shares of Japan's Imports}

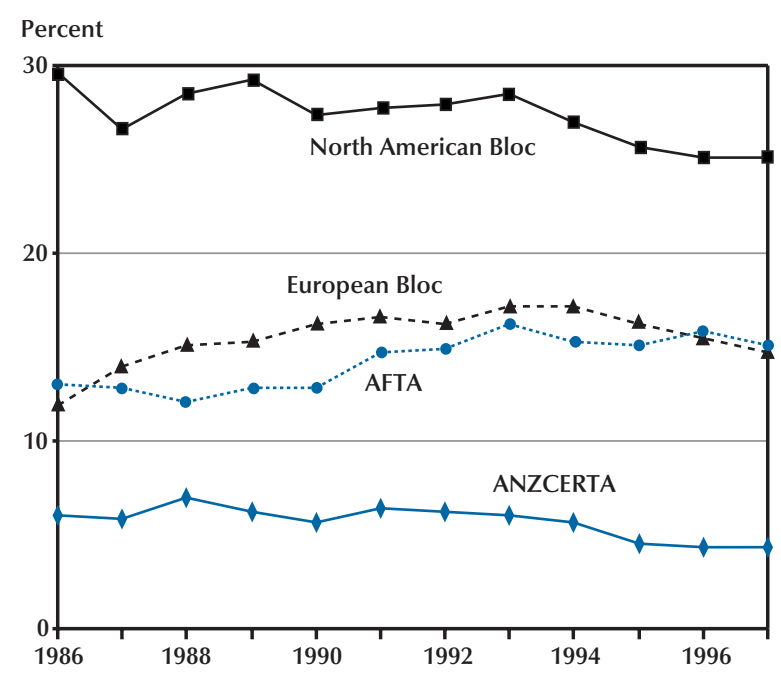

SOURCE: World Trade Flows 1980-97.

the European Community deepened its integration and renamed itself the European Union.

A disaggregation of total Japanese trade into imports and exports, as in Figures 5 and 6, reveals even more about the potential effects of integration on the distribution of Japan's trade. Most of the decline in North America's share of total Japanese trade has been in its share of Japanese exports, although its import and export shares both dropped noticeably following the two stages of North American integration. For post-1992 trade, European bloc members saw their share of Japanese exports drop more sharply than their share of Japanese imports. Meanwhile, the shares for the members of AFTA trended upward for both imports and exports, although the larger increase was in the share of Japanese exports going to these countries. In 1986, AFTA members received less than half as much of Japanese exports that European bloc members received, but by 1997 they received an equal share. In contrast, the blocs' shares of Japanese imports were very similar throughout the period.

Hand in hand with the trends in the geographic components of Japan's trade are the trends in the mix of goods that Japan imports and exports (Ministry of International Trade and Industry [MITI], 1998). Over the period, Japan's imports have shifted away from raw materials and toward manufactured goods, particularly to parts of machinery and trans- 
portation equipment. Much of this shift has been reflected in increased shares of these goods from East Asian countries, and a decreased share from the United States. On the export side, the share of capital goods continued to increase as it had since the 1970s, which can be attributed to the growing presence of Japanese firms with production facilities inside overseas markets (MITI, 1998). ${ }^{9}$ Instead of producing all of the consumer durables that its firms sell in these markets, Japan exported more machines and intermediate products, assembling the consumer durables in the markets where they were sold (or were even exported from this new production base). Of course, the other side of this trend is that exports of durable consumer goods such as automobiles decreased at the same time. However, these changes have not had the geographic dimension that was apparent on the imports side.

\section{THE EMPIRICAL MODEL}

Although the trends in the geographic distribution of Japan's trade illustrated by Figures 4 through 6 are consistent with what one might expect following the formation of RTBs, they are only suggestive. While they suggest that Japanese trade levels have been affected adversely by North American and European integration, they should not be taken too seriously, because they control for very few of the many determinants of trade. To obtain more rigorous estimates of the effects of RTBs on Japanese trade, I use a gravity model, which recently has become the workhorse of empirical studies of international integration.

The gravity model of international trade assumes that the volume of bilateral trade can be estimated as an increasing function of the sizes of the trading economies, and a decreasing function of the geographic distance between them. In Tinbergen (1962) and Pöyhönen (1963), the sizes of the economies were measured simply by their national incomes, although, since Linnemann (1966), it has been common to add their populations or per capita incomes to the model. To control for various other factors, it has also been standard to include dummy variables to indicate when trading partners have colonial or linguistic links, are contiguous, are islands, etc. (for a survey, see Oguledo and MacPhee, 1994). For many years, the gravity model was criticized as being ad hoc, although recent theoretical justifications for it have led to its wider acceptance. Recently, for example, Deardorff (1998) showed that the gravity model can be consistent with several standard trade models.
Gravity models have been used to examine Japanese trade by Eaton and Tamura $(1994,1996)$, who looked at differences between Japanese and U.S. trade and direct foreign investment patterns. Alternatively, vector autoregression methods have been used by Ceglowski (1996), Daly (1998), and Nadenichek (2000) to examine, respectively, the late 1980s surge in U.S. imports from Japan, the effect of exchange rate volatility on Japanese trade, and the Japan-U.S. trade imbalance in a real business cycle model. Also, see Sawyer and Sprinkle (1997) for a survey of the empirical international economics literature as it applies to Japanese trade.

The gravity model I estimate is standard, except that, following Mátyás (1997), Bayoumi and Eichengreen (1997), and Cheng and Wall (2002), I allow the intercept to differ across trading partners. Specifically, I estimate

(1)

$$
\begin{aligned}
\ln \left(x_{i j t}\right) & =\alpha_{0}+\alpha_{i j}+\gamma \mathbf{T}_{\mathbf{i j t}}^{\prime}+\beta_{1} \ln Y_{i t}+\beta_{2} \ln Y_{j t} \\
& +\beta_{3} \ln y_{i t}+\beta_{4} \ln y_{j t}+\delta \ln D_{i j} \\
& +\sum_{b=1}^{6}\left(\begin{array}{l}
\theta_{1}^{b} I_{i j t}^{b}+\theta_{2}^{b} M_{i j t}^{b}+\theta_{3}^{b} X_{i j t}^{b} \\
+\theta_{4}^{b} M J_{i j t}^{b}+\theta_{5}^{b} X J_{i j t}^{b}
\end{array}\right)+\varepsilon_{i j t},
\end{aligned}
$$

where $x_{i j t}$ is real exports from country $i$ to country $j$ in year $t, Y_{i t}$ and $Y_{j t}$ are their real GDPs, $y_{i t}$ and $y_{j t}$ are their real per capita GDPs, and $D_{i j}$ is the distance between them. In addition to these gravity variables, equation (1) also includes a vector of time dummies $\mathbf{T}_{\mathrm{ijt}}$; a trading-pair effect, $\alpha_{i j}$, that is fixed over time; and 30 integration dummies.

Gravity models usually include variables to capture fixed factors that are thought to affect bilateral trade, including dummies for contiguity and a common language, among others. In equation (1), these factors are all subsumed into trading-pair fixed effects. Specifically, $\alpha_{i j}=\omega \mathbf{Z}_{\mathbf{i j}}^{\prime}$, where $\mathbf{Z}_{\mathbf{i j}}$ is a vector of all of the fixed factors that make the volume of exports from $i$ to $j$ differ from the average, and $\omega$ is a vector of their weights. Rather than trying to specify all of the unknown number of these variables, which may or may not even be observable, I simply specify their total effect as a trading-pairspecific intercept term. Further, because $\alpha_{i j}$ and $\delta \ln D_{i j}$ cannot be estimated separately, I estimate their sum as a fixed effect, $\pi_{i j}=\alpha_{i j}+\delta \ln D_{i j}$, using a dummy variable for each of the trading pairs. A

\footnotetext{
9 See Abe and Zhao (2000), Kimura (2000), and Lipsey (2000) for studies of the geographic and sectoral dimensions of Japanese direct foreign investment.
} 
trading-pair dummy takes the value of one whenever the observation is of exports from $i$ to $j$ and is zero otherwise. 10

Using fixed-effects estimation allows me to capture the influence of not only distance and other fixed variables normally specified in gravity models, but also of any number of important factors that may be difficult or impossible to quantify and, therefore, are normally excluded. As shown by Cheng and Wall $(2001,2002)$, excluding these variables (which is the same as restricting their effects to be the same across states and countries) results in serious estimation bias. In particular, they show how the usual estimation methods hugely overestimate the effects of RTBs on trade because they do not properly account for the possibility that there are factors responsible for both high levels of trade between members and the probability that they will join the same RTB.

Another advantage of modeling these factors as fixed effects is that it allows me to avoid the ad hoc measures of distance normally used, while still controlling for the effects of distance on trade volume. Distance in gravity models is usually simply the great circle distance between the capital cities or the geographic centers of the two countries, which is clearly unsatisfactory.

The variables of most present interest are the integration dummies. For each of the six RTBs, I specify five dummy variables to capture each of its effects on trade. The first three of these capture the effects on, respectively, trade between members, member imports from nonmembers, and member exports to nonmembers. The other two are used to separate out the Japan-specific effects and capture an RTB's effects on member imports from Japan and on member exports to Japan. In equation (1), the RTB dummy variables are $I_{i j t}^{b}$, which is equal to one if $i$ and $j$ are both members of bloc $b$ in year $t$; $M_{i j t}^{b}$, which is equal to one when $j$ is a member of bloc $b$ in year $t$ (and $i$ is not Japan); $X_{i j t}^{b}$, which is equal to one when $i$ is a member of bloc $b$ in year $t$ (and $j$ is not Japan); $M J_{i j t}^{b}$, which is equal to one when $j$ is a member of bloc $b$ in year $t$ and $i$ is Japan; and $X J_{i j t}^{b}$, which is equal to one when $i$ is a member of bloc $b$ in year $t$ and $j$ is Japan.

This specification of integration dummies differs from what is found in most of the gravity model literature in that, following Soloaga and Winters (2001), it includes dummies to capture the effects on member exports. ${ }^{11}$ As reviewed by Soloaga and Winters, not only are member exports almost never consid- ered, but many studies do not even consider the effects of RTBs on member imports, despite the prominence of trade diversion in any discussion of RTBs. Further, even when studies do consider member exports, they assume without any theoretical basis that the RTB will have the same effect on member exports as it will have on member imports.

As discussed above, the theoretical literature on the effects of RTBs on trade is rather sparse, so there are no definitive expected signs on the integration dummies in equation (1). Vinerian trade creation would suggest a positive sign for the effect on intra-bloc trade $\theta_{1}^{b}$, and Vinerian trade diversion would suggest a negative sign for the effect on bloc-member exports out of the bloc $\theta_{2}^{b}$ and $\theta_{4}^{b}$. As mentioned above, several studies simply combine the effects on imports and exports, implying that $\theta_{3}^{b}$ and $\theta_{5}^{b}$ are also expected to have negative signs. However, in a standard general equilibrium model it is not possible to determine the signs of an RTB's effects on trade with nonmembers. As discussed above, further difficulty in assigning expected signs arises when you consider the geography of production decisions and changes in tariff levels following integration.

\section{THE EMPIRICAL RESULTS}

To estimate equation (1), I use bilateral trade data from the World Trade Flows data set, GDP and population data from the World Bank, and inflation data from the Bureau of Labor Statistics. Using observations for four years $(1982,1987,1992$, and 1997) and 71 countries, I construct a balanced panel of 3,321 trading pairs per year for a total of 13,284 observations. ${ }^{12}$

In creating the integration dummies, some judgment must be made about the timing of the RTBs. This is because the date at which an RTB is actually implemented may not correspond to when it begins to affect trade. Trade may be affected even before an RTB is formally in place, as firms begin trading

\footnotetext{
10 This is the least restrictive specification of fixed effects and follows Bayoumi and Eichengreen (1997) and Cheng and Wall (2001, 2002). In contrast, Mátyás (1997) assumes that each country has two fixed effects, one as an importer and one as an exporter. See Cheng and Wall (2002) for an evaluation of the different specifications.

11 See Cheng and Wall (2001) for another multicountry study of the effects of RTBs that estimates separate effects for member imports and exports. In addition, Coughlin and Wall (2000) and Wall (2000) estimate the effects of NAFTA on member-country exports.

12 Note that I do not have observations of trade between all pairs of these countries.
} 
in advance of the barriers actually falling so as to establish themselves in new markets. Also, some RTBs, such as AFTA, are formalized well before trade barriers begin to fall significantly, while others lead to significant reductions in trade barriers immediately after formal implementation.

Keeping these problems in mind, my integration dummies are constructed according to the descriptions in Frankel (1997). An RTB is assumed to begin having an effect when it is formally implemented or when a country becomes a member of an existing bloc. Note that, because of evolving names and membership, the various North American and European regimes are collected into two meta-RTBs: the North American bloc and the European bloc.

Results for the least squares estimation of equation (1) are in Table 1, which provides the estimated coefficients, the White-corrected standard errors, and $t$ statistics. In addition, the last column of the table provides the percentage change in trade implied by the point estimates of the coefficients on the integration and time dummies [100 $\left.\times\left(e^{\text {coeff. }}-1\right)\right]$. Because of space considerations, I do not report the estimates of the 3,321 trading-pair fixed effects.

The estimated coefficients on the four gravity variables are not surprising and indicate that real trade was positively related with the countries' real GDPs and negatively related with their real per capita GDPs. Because of the perfect collinearity of the time dummies, the dummy for 1982 was excluded, meaning that the remaining time dummies indicated changes in trade relative to 1982 .

As the results in Table 1 indicate, the six RTBs tended to have positive and statistically significant effects on their members' trade with each other. As for their effects on their members' trade with Japan and the rest of the world, there was not nearly as much consistency in sign or magnitude. Contrary to trade diversion, only one of the RTBs had a significant negative effect on imports from the rest of the world, although their effects on exports to the rest of the world did tend to be negative. As discussed in more detail below, the effects of the RTBs on members' trade with Japan tended to differ a great deal from their effects on members' trade with the rest of the world. As the present focus is Japan, the aggregated effects of the RTBs from Japan's perspective are provided in Table 2 . These numbers are calculated by simply taking the point estimates of the effects of the RTBs on trade with Japan and applying them to the actual levels of trade for 1997.

\section{A. North American Bloc}

As reported in Table 1, I find that the North American trading bloc has had relatively large effects on all five categories of trade, especially intra-bloc trade, which was 57 percent higher because of the bloc. For trade with nonmembers, the bloc's effects were varied, affecting the members' trade with Japan differently from their trade with the rest of the world. Specifically, because of the bloc, member imports from the rest of the world were 18 percent higher, while member imports from Japan were 17 percent lower. Also, member exports to the rest of the world and to Japan were both lower because of the bloc, although the 37 percent decrease in exports to Japan was more than twice the effect on exports to the rest of the world.

As shown in Table 2, combining the negative effects that the North American bloc had on both directions of trade with Japan indicates that the bloc led to a decrease in total trade of US\$53 billion in 1997 , or 25 percent of members' total trade with Japan. Because the North American bloc is by far the most important RTB from Japan's perspective, this represented a significant decline in Japanese trade with the world. Specifically, because of the North American bloc, total Japanese exports and imports were, respectively, 5.4 percent and 9.2 percent lower, implying a 7 percent decrease in Japanese total trade with the world.

\section{B. European Bloc}

The estimated effects of the European bloc on trade are very different from those of the North American bloc. First, contrary to the predictions of Vinerian trade creation, I find that the European bloc had virtually no effect on trade between members. On the other hand, consistent with Vinerian trade diversion, I find that member imports from Japan and the rest of the world were, respectively, 36 percent and 11 percent lower because of the RTB. Interestingly, while member exports to the rest of the world were 22 percent lower, member exports to Japan were 31 percent higher.

As shown in Table 2, the opposing large effects of the European bloc on Japanese imports and exports meant that Japan's total trade with bloc members in 1997 was 8.7 percent, or US\$10 billion, lower because of the bloc. In terms of Japan's trade with the world, the effect of the bloc was a 5.9 percent decrease in exports and a 4.6 percent increase in imports, for a decrease in total trade of 1.4 percent. 


\section{Table 1}

Regression Results (Dependent Variable $=$ Log of Real Exports)

\begin{tabular}{|c|c|c|c|c|}
\hline & Coefficient & Robust s.e. & $t$ statistic & Percentage change \\
\hline Constant & -5.919 & 1.175 & -5.038 & \\
\hline Log of real exporter GDP & 1.244 & 0.208 & 5.985 & \\
\hline Log of real importer GDP & 1.554 & 0.201 & 7.723 & \\
\hline Log of per capita exporter GDP & -0.780 & 0.192 & -4.063 & \\
\hline Log of per capita importer GDP & -1.030 & 0.183 & -5.644 & \\
\hline 1987 dummy & -0.019 & 0.032 & -0.584 & -1.8 \\
\hline 1992 dummy & -0.048 & 0.055 & -0.868 & -4.7 \\
\hline 1997 dummy & 0.045 & 0.075 & 0.603 & 4.6 \\
\hline \multicolumn{5}{|l|}{ North American bloc } \\
\hline Intra-bloc trade & 0.448 & 0.138 & 3.243 & $56.6^{*}$ \\
\hline Imports from rest of the world & 0.167 & 0.060 & 2.785 & $18.2^{*}$ \\
\hline Exports to rest of the world & -0.188 & 0.055 & -3.399 & $-17.2^{*}$ \\
\hline Imports from Japan & -0.196 & 0.092 & -2.129 & $-17.8^{*}$ \\
\hline Exports to Japan & -0.454 & 0.213 & -2.135 & $-36.5^{*}$ \\
\hline \multicolumn{5}{|l|}{ European bloc } \\
\hline Intra-bloc trade & -0.025 & 0.063 & -0.391 & -2.4 \\
\hline Imports from rest of the world & -0.116 & 0.065 & -1.779 & -10.9 \\
\hline Exports to rest of the world & -0.248 & 0.044 & -5.628 & $-21.9 *$ \\
\hline Imports from Japan & -0.444 & 0.103 & -4.330 & $-35.9 *$ \\
\hline Exports to Japan & 0.273 & 0.111 & 2.460 & $31.4^{*}$ \\
\hline \multicolumn{5}{|l|}{ AFTA } \\
\hline Intra-bloc trade & 0.322 & 0.135 & 2.387 & $38.0 *$ \\
\hline Imports from rest of the world & 0.239 & 0.091 & 2.643 & $27.0^{*}$ \\
\hline Exports to rest of the world & 0.307 & 0.075 & 4.102 & $35.9 *$ \\
\hline Imports from Japan & 0.001 & 0.136 & 0.010 & 0.1 \\
\hline Exports to Japan & -0.096 & 0.166 & -0.582 & -9.2 \\
\hline \multicolumn{5}{|l|}{ ANZCERTA } \\
\hline Intra-bloc trade & 0.069 & 0.054 & 1.283 & 7.1 \\
\hline Imports from rest of the world & 0.091 & 0.116 & 0.789 & 9.6 \\
\hline Exports to rest of the world & 0.127 & 0.115 & 1.110 & 13.6 \\
\hline Imports from Japan & -0.684 & 0.113 & -6.057 & $-49.5^{*}$ \\
\hline Exports to Japan & -0.388 & 0.085 & -4.570 & $-32.1^{*}$ \\
\hline \multicolumn{5}{|l|}{ Mercosur } \\
\hline Intra-bloc trade & 0.334 & 0.108 & 3.101 & $39.6^{*}$ \\
\hline Imports from rest of the world & 0.770 & 0.103 & 7.458 & $115.9 *$ \\
\hline Exports to rest of the world & -0.362 & 0.091 & -3.966 & $-30.4^{*}$ \\
\hline Imports from Japan & -0.069 & 0.140 & -0.490 & -6.6 \\
\hline Exports to Japan & -0.381 & 0.214 & -1.777 & -31.7 \\
\hline \multicolumn{5}{|l|}{ Andean Community } \\
\hline Intra-bloc trade & 0.560 & 0.205 & 2.731 & $75.1^{*}$ \\
\hline Imports from rest of the world & 0.230 & 0.083 & 2.769 & $25.9 *$ \\
\hline Exports to rest of the world & 0.048 & 0.111 & 0.436 & 4.9 \\
\hline Imports from Japan & -0.520 & 0.214 & -2.423 & $-40.5^{*}$ \\
\hline Exports to Japan & -0.238 & 0.354 & -0.672 & -21.1 \\
\hline
\end{tabular}

Number of observations $13,284, \overline{\mathrm{R}}^{2}=0.898, \mathrm{RMSE}=0.907$

NOTE: The estimates of the 3,321 fixed effects are suppressed for space considerations. Asterisks indicate a percentage effect that is statistically significant at the 5 percent level. 


\section{Table 2}

Aggregated Effects of Trade Blocs on Japanese Trade, 1997

\begin{tabular}{|c|c|c|c|c|}
\hline & $\begin{array}{l}\text { Actual } 1997 \text { trade } \\
\text { (US\$ billions) }\end{array}$ & $\begin{array}{l}\text { Effect as percentage } \\
\text { of trade with bloc }\end{array}$ & $\begin{array}{l}\text { Effect in } \\
\text { US\$ billions }\end{array}$ & $\begin{array}{l}\text { Effect as percentage } \\
\text { of trade with world }\end{array}$ \\
\hline \multicolumn{5}{|l|}{ North American bloc } \\
\hline Japanese exports & 130.6 & -17.8 & -23.2 & -5.4 \\
\hline Japanese imports & 80.9 & -36.5 & -29.5 & -9.2 \\
\hline Total trade with Japan & 211.5 & -25.0 & -52.8 & -7.0 \\
\hline \multicolumn{5}{|l|}{ European bloc } \\
\hline Japanese exports & 69.9 & -35.9 & -25.1 & -5.9 \\
\hline Japanese imports & 47.5 & 31.4 & 14.9 & 4.6 \\
\hline Total trade with Japan & 117.4 & -8.7 & -10.2 & -1.4 \\
\hline \multicolumn{5}{|l|}{ AFTA } \\
\hline Japanese exports & 68.8 & 0.1 & 0.1 & 0.0 \\
\hline Japanese imports & 48.7 & -9.2 & -4.5 & -1.4 \\
\hline Total trade with Japan & 117.5 & -3.8 & -4.4 & -0.6 \\
\hline \multicolumn{5}{|l|}{ ANZCERTA } \\
\hline Japanese exports & 9.5 & -49.5 & -4.7 & -1.1 \\
\hline Japanese imports & 13.8 & -32.1 & -4.4 & -1.4 \\
\hline Total trade with Japan & 23.4 & -39.2 & -9.2 & -1.2 \\
\hline \multicolumn{5}{|l|}{ Mercosur } \\
\hline Japanese exports & 4.8 & -6.6 & -0.3 & -0.1 \\
\hline Japanese imports & 4.0 & -31.7 & -1.3 & -0.4 \\
\hline Total trade with Japan & 8.7 & -18.0 & -1.6 & -0.2 \\
\hline \multicolumn{5}{|l|}{ Andean Community } \\
\hline Japanese exports & 2.4 & -40.5 & -1.0 & -0.2 \\
\hline Japanese imports & 1.2 & -21.1 & -0.2 & -0.1 \\
\hline Total trade with Japan & 3.6 & -34.1 & -1.2 & -0.2 \\
\hline \multicolumn{5}{|l|}{ Total for all blocs } \\
\hline Japanese exports & 286.0 & -19.0 & -54.3 & -12.7 \\
\hline Japanese imports & 196.0 & -12.8 & -25.0 & -7.8 \\
\hline Total trade with Japan & 482.1 & -16.5 & -79.3 & -10.6 \\
\hline
\end{tabular}

NOTE: The trade data in the second column are from World Trade Flows, and the numbers in the shaded areas are from the last column of Table 1. Other numbers are the author's calculations.

\section{AFTA}

I find that because of the formation of AFTA, intra-bloc trade and members' trade with the nonJapanese world were both much higher. Intra-bloc trade increased by 38 percent, while imports from and exports to the rest of the world rose by 27 percent and 36 percent, respectively. On the other hand, the estimated effects of AFTA on trade with
Japan were both statistically no different from zero, leaving Japan out of the AFTA trade boom.

In terms of trade volume, AFTA members are collectively as important to Japan as the members of the European bloc. Nevertheless, by 1997, AFTA did not have much of an effect on Japan. Clearly, though, the jury is still out on the effects of AFTA on Japanese trade as the relative newness and shallowness of AFTA integration are likely responsible 
for both the small estimated effects and the large standard errors. From a Japanese perspective, this RTB is perhaps the most interesting for future research, because the effects of the other two large blocs are probably already firmly established.

\section{ANZCERTA}

The only significant effects that I find for the ANZCERTA are the large decreases in member trade with Japan. As with AFTA and NAFTA, this agreement has been much worse for Japan than for the rest of the world, having relatively little effect on trade between members and the rest of the world other than Japan. It has decreased members' imports from Japan by 50 percent and member exports to Japan by 32 percent. In total, this indicated a 39 percent drop in members' total trade with Japan and a 1.2 percent decrease in Japan's total trade with the world.

\section{E. Mercosur}

The estimated effects of Mercosur are fairly large and pronounced, even though this RTB was formed relatively recently. I find that, because of Mercosur, trade between members was 40 percent higher, imports from the rest of the world were 116 percent higher, and exports to the rest of the world were 30 percent lower. It had very little effect on its members' imports from Japan, although it decreased their exports to Japan by 32 percent. Combining these effects, members' total trade with Japan was 18 percent lower because of Mercosur. Since members of this RTB accounted for less than 2 percent of Japanese trade with the world, it has not had a large effect on Japan.

\section{F. Andean Community}

As with most of the other RTBs, the formation of the Andean Community has led to a large increase in trade between members and imports from the rest of the world. Japan has not shared in this, however, as member imports from Japan were 41 percent lower in 1997 because of the RTB. Because members of the Andean Community's share of Japanese exports was less than 1 percent of the total, this RTB has so far had little effect on Japan's overall trade.

\section{G. Total for AII Blocs}

To illustrate how regional integration as a whole has affected Japanese trade, the bottom of Table 2 presents the aggregated effects of the six RTBs on 1997 trade. Primarily because of the large negative effects of the two largest RTBs, the North American and European blocs, the total effect on Japanese exports to RTB members was a decrease of 19 percent, or US\$54 billion. On the imports side, the large positive effect of the European bloc softened the large negative effect of the North American bloc, making the total effect in Japanese imports from RTB members a 12.8 percent, or US\$2 5 billion, decrease. The combined decreases in Japanese exports and imports meant a 16.5 percent, or US\$79 billion, decrease in Japanese total trade with members of these RTBs.

Because the members of these six RTBs accounted for more than 60 percent of Japan's trade, the total effects of the RTBs were significant in terms of their effects on total Japanese trade with the world. Specifically, their total effects meant a 12.7 percent decrease in Japanese exports, a 7.8 percent decrease in Japanese imports, and a 10.6 percent decrease in Japanese total trade.

\section{CONCLUDING REMARKS}

This study is a first step in understanding the effects of regional integration on Japan. Despite recent trends toward regional integration, Japan, the world's second largest economy, has so far resisted joining an RTB. Because more than 60 percent of Japan's trade is with countries that are members of a major RTB, its reluctance may have had significant effects on its pattern and volume of trade. Indeed, I find that Japanese trade, especially Japanese exports, has been reduced by the regional integration of its trading partners. Specifically, I find that if none of these RTBs were in place, Japan's 1997 total trade volume would have been nearly 11 percent higher than it was-exports and imports would have been almost 13 and 8 percent higher, respectively. As noted above, there is still some uncertainty about the eventual effects of some of the RTBs, as several are relatively new and not nearly as deeply integrated as the North American and European blocs. In particular, as the members of AFTA become more integrated over time, its effects on Japan are likely to become clearer and more pronounced than those found in this study.

Perhaps the most curious aspect of my results, though, is that the effects of the RTBs on Japan tended to differ a great deal from their effects on the rest of the world, almost always being much more negative. This finding presents the most obvious direction for future research, which should include sectoral- or industry-level analysis, with 
attention paid to the differences between intermediate and final goods. This is likely to be particularly important given the high mobility of Japanese firms and capital and the endogeneity of the productionlocation decision. Also, although Head and Ries (2001) find that Japanese exports of intermediate goods tend to follow manufacturing investment overseas, for key firms this was not true. Overseas investment by large automobile assemblers such as Toyota, Nissan, and Honda instead led to net decreases in their exports. Similarly, Lipsey, Ramstetter, and Blomström (2000) find differences across Japanese industries.

\section{REFERENCES}

Abe, Kenzo and Zhao, Laixun. "International Joint Ventures, Economic Integration, and Government Policy," in Takatoshi Ito and Anne O. Krueger, eds., The Role of Foreign Direct Investment in East Asian Economic Development. Chicago: University of Chicago Press, 2000.

Anderson, Kym and Snape, Richard H. "European and American Regionalism: Effects on and Options for Asia." Journal of the Japanese and International Economies, December 1994, 8(4), pp. 454-77.

Bandyopadhyay, Subhaya and Wall, Howard J. "Customs Union or Free Trade Area? The Role of Political Asymmetries." Review of International Economics, November 1999, 7(4), pp. 665-72.

Bayoumi, Tamim and Eichengreen, Barry. "Is Regionalism Simply a Diversion? Evidence from the Evolution of the EC and EFTA," in Takatoshi Ito and Anne O. Krueger, eds., Regionalism versus Multilateral Trade Arrangements. Chicago: University of Chicago Press, 1997.

Ceglowski, Janet. "The Recent Behavior of Japanese Imports: A Disaggregated Analysis." Japan and the World Economy, December 1996, 8(4), pp. 443-57.

Cheng, I-Hui and Wall, Howard J. "Estimates of the Effects of Regional Integration on Trade." Working paper, Federal Reserve Bank of St. Louis, 2001.

and . "Controlling for Heterogeneity in Gravity Models of Trade and Integration.” Working Paper 99-010C, Federal Reserve Bank of St. Louis, 2002.

Coughlin, Cletus. C. and Wall, Howard J. "NAFTA and the Changing Pattern of State Exports." Working Paper 2000029A, Federal Reserve Bank of St. Louis, February 2000 (forthcoming in Papers in Regional Science).
Daly, Kevin. "Does Exchange Rate Volatility Impede the Volume of Japan's Bilateral Trade?" Japan and the World Economy, July 1998, 10(3), pp. 333-48.

Deardorff, Alan V. "Determinants of Bilateral Trade: Does Gravity Work in a Neoclassical World?” in Jeffrey A. Frankel, ed., The Regionalization of the World Economy. Chicago: University of Chicago Press, 1998.

Eaton, Jonathan and Tamura, Akiko. "Bilateralism and Regionalism in Japanese and U.S. Trade and Direct Foreign Investment Patterns," Journal of the Japanese and International Economies, December 1994, 8(4), pp. 478-510. and "Japanese and U.S. Exports and Investment as Conduits of Growth," in Anne O. Krueger and T. Ito, eds., Financial Deregulation and Integration in East Asia. Chicago: University of Chicago Press, 1996.

Eguchi, Masato. "JSEPA (Japan-Singapore Economic Partnership Agreement) and Future Trade Policy." Journal of Japanese Trade and Industry, January/February 2001, 20(1).

Feenstra, Robert C. "World Trade Flows, 1980-1997." Center for International Data, University of California, Davis, March 2000.

Frankel, Jeffrey A. Regional Trading Blocs in the World Economic System. Washington, DC: Institute for International Economics, 1997.

Goto, Junichi and Hamada, Koichi. "Economic Integration and the Welfare of Those Who Are Left Behind: An Incentive Theoretic Approach." Journal of the Japanese and International Economies, 1998, 12(1), pp. 25-48.

and "Regional Economic Integration and Article XXIV of the GATT." Review of International Economics, November 1999, 7(4), pp. 555-70.

Greaney, Theresa. "An Analysis of Japan's Changing Import Behavior." Working paper, University of Hawaii, Manoa, 2001.

Head, Keith and Ries, John. "Overseas Investment and Firm Exports.” Review of International Economics, February 2001, 9(1), pp. 108-22.

Kimura, Fukanari. "Location and Internalization Decisions: Sector Switching in Japanese Outward Foreign Direct 
Investment," in Takatoshi Ito and Anne O. Krueger, eds., The Role of Foreign Direct Investment in East Asian Economic Development. Chicago: University of Chicago Press, 2000.

Kojima, Akira. "Free Trade Agreements as Constructive Regionalism." Journal of Japanese Trade and Industry, January/February 2001, 20(1).

Kose, M. Ayhan and Riezman, Raymond. "Understanding the Welfare Implications of Preferential Trade Agreements." Review of International Economics, November 2000, 8(4), pp. 619-33.

Linnemann, Hans. An Econometric Study of International Trade Flows. Amsterdam: North-Holland, 1966.

Lipsey, Robert E. "Affiliates of U.S. and Japanese Multinationals in East Asian Production and Trade," in Takatoshi Ito and Anne O. Krueger, eds., The Role of Foreign Direct Investment in East Asian Economic Development. Chicago: University of Chicago Press, 2000.

; Ramstetter, Eric and Blomström, Magnus.

"Outward FDI and Parent Exports and Employment: Japan, the United States, and Sweden." Global Economy Quarterly, September-October 2000, 1, 285-302.

Mátyás, Laszlo. "Proper Econometric Specification of the Gravity Model.” The World Economy, May 1997, 20(3), pp. 363-68.

Ministry of Economy, Trade, and Industry. 2001 Report on the WTO Consistency of Trade Policies by Major Trading Partners. 2001

Ministry of International Trade and Industry. White Paper on International Trade, 1998. 1998.

Nadenichek, Jon. "The Japan-U.S. Trade Imbalance: A Real Business Cycle Perspective." Japan and the World Economy, August 2000, 12(3), pp. 255-71.

Oguledo, Victor I. and MacPhee, Craig R. “Gravity Models:
A Reformulation and an Application to Discriminatory Trade Arrangements." Applied Economics, February 1994, 26(2), pp. 107-20.

Pöyhönen, P. "A Tentative Model for the Volume of Trade Between Countries." Weltwirtschaftliches Archive, 1963, 90, pp. 93-100.

Sawyer, W. Charles and Sprinkle, Richard L. "The Demand for Imports and Exports in Japan: A Survey." Journal of the Japanese and International Economies, June 1997, 11(2), pp. 247-59.

Soloaga, Isidro and Winters, L. Alan. "Regionalism in the Nineties: What Effect on Trade?" The North American Journal of Economics and Finance, March 2001, 12(1), pp. $1-29$.

Tinbergen, Jan. Shaping the World Economy: Suggestions for an International Economic Policy. New York: The Twentieth Century Fund, 1962.

Wall, Howard J. "NAFTA and the Geography of North American Trade.” Working Paper 2000-17B, Federal Reserve Bank of St. Louis, November 2000.

Winters, L. Alan. "Regionalism and the Rest of the World: The Irrelevance of the Kemp-Wan Theorem." Oxford Economic Papers, April 1997, 49(2), pp. 228-34. and Chang, Won. "Regional Integration and Import Prices: An Empirical Investigation.” Journal of International Economics, August 2000, 51(2), pp. 363-77.

Viner, Jacob. The Customs Union Issue. Carnegie Endowment for International Peace, 1950.

Yi, Sang-Seung. "Free Trade Areas and Welfare: An Equilibrium Analysis." Review of International Economics, May 2000, 8(2), pp. 336-47. 